\title{
The growing educational divide in mothers' employment: An investigation based on the German micro-censuses 1976-2004
}

\author{
Dirk Konietzka \\ Braunschweig University - Institute of Technology \\ Michaela Kreyenfeld \\ Max Planck Institute for Demographic Research
}

\begin{abstract}
This article investigates whether the increase in the labour force participation of mothers in western Germany has been accompanied by growing social inequalities in maternal employment. The focus is on education-related differences in full-time, parttime and marginal employment, and, in particular, changes therein over time. It is assumed that worsening labour market opportunities for the less educated and a 'familialistic' social policy context have resulted in growing differentials in mothers' employment by education. Data from the scientific use files of the German microcensuses for the years 1976 to 2004 show that the part-time and marginal employment rates of mothers have increased, while full-time employment rates have declined. Reductions in full-time employment are most pronounced among less educated mothers, resulting in growing educational differences in the employment of mothers.
\end{abstract}

\section{Keywords}

education, female labour force participation, male breadwinner model, micro-census, western Germany

\section{Introduction}

It is widely acknowledged that, in Western societies, female labour force participation has been steadily increasing since the 1960s. The changing employment patterns of 
women are strongly related to shifting gender inequalities, family structures and labour markets, suggesting that women's growing attachment to the labour market is a core issue of social change during the last decades. Research has shown that the increase in female labour force participation has resulted predominantly from changes in the employment behaviour of married women, and particularly of mothers with dependent children (Oppenheimer 1994; Blossfeld 1995). Married women have become less willing to play the traditional role of full-time homemakers, and those with children have returned more often, and more quickly, to paid work after childbirth. Fuelled by these changes, the male breadwinner family model, it is often argued, has been gradually replaced by a more gender equal, dual breadwinner arrangement (Daly 2005, p. 383).

Previous research has shown, however, that full-time employment of married women, and especially of mothers, has become a new, dominant model only in a few countries, notably the United States (Waite and Nielsen 2001). In many European countries, the influx of married women into the labour market has resulted primarily in a growth in marginal and part-time employment (Blossfeld and Hakim 1997; Bothfeld et al. 2005; Hakim 2000; OECD 2004; Wielers and van der Meer 2003; Haas et al. 2006). Studies which try to map the labour market situation of women in contemporary societies have concluded that gender inequalities persist in terms of full-time employment, career opportunities, unpaid housework and care work, as well as in work-lifestyle preferences (Hakim 2000; Blossfeld and Drobniĉ 2001; Pascall and Lewis 2004; Mandel and Semyonov 2006; Duncan et al. 2009).

Apart from gender differences in employment behaviour, there has been concern that inequalities between families are on the rise (Maxwell 1990; Lichter and Eggebeen 1994; McLanahan 2004; Esping-Andersen 2009). There is a large body of literature that documents educational differences in female employment behaviour. Better educated women are more often employed, and, if they have children, they return to the labour market faster than other women (Ondrich et al. 1996; Kurz 1998; Drobnič 2000). They also express more 'modern ideas' regarding maternal employment, and are able to realise these ideas more easily than less educated women. Such differences in employment behaviour are likely to transfer into socio-economic inequalities at the 
household level. In this sense, the increase in maternal employment raises new issues of social inequality between families.

This article focuses on the employment patterns of mothers through the lens of social inequality. It raises the question of whether there is a growing educational divide in maternal employment patterns over time. The main focus of this study is on changes with respect to mothers working full-time, following the assumption that female fulltime employment is a more central indicator for gender equality than merely labour force participation (cf. Crompton et al. 2005). It is not only that full-time jobs offer better career opportunities than do part-time jobs, but also that full-time participation in the labour market is a main factor in the economic independence of women (Sørensen and McLanahan 1987; Lewis 1992; Klement and Rudolph 2004). By the same token, it is the woman's full-time employment that primarily defines whether a couple is following a 'male breadwinner model' or a gender equal 'dual earner arrangement'. Hence, this study differs somewhat from studies that focus mainly on women's part-time employment (Debacker 2008, Gash 2008), their working time preferences (Hakim 2000), or issues of work-life balance (Bonney 2005, Dex and Bond 2005).

This study makes use of data from the scientific use files of the German microcensuses 1976 to 2004. Some of these data have only recently become available for research purposes, and they allow researchers to greatly broaden the scope of empirical analyses regarding educational differences in female employment, and changes therein. Data are highly comparable across years, and sample sizes are sufficiently large to enable researchers to conduct sound analyses. Last but not least, with this data it is possible take into account partner and household characteristics.

The paper is structured as follows. The next section provides an elaboration of the theoretical considerations. The main argument evolves around the hypothesis that there has been a growing educational divide in maternal employment patterns in western Germany since the 1970s. The following sections describe the data and present the empirical results, and the final section summarises the main findings.

\section{Theoretical considerations}


In the following, two major factors that have an impact on mothers' employment are considered: first, rising educational levels and the growing relevance of education for labour market careers; and, second, the incentives and constraints imposed by social policies.

\section{Education and employment}

In economic as well as sociological literature, education is considered a key factor in determining labour market behaviour. Economic models view education as an essential element of a person's human capital. Better educated people have greater incentives to work than less educated individuals because they can expect higher wages (Mincer 1974). While economic theory considers expected wages as a central determinant in employment decisions, sociological approaches also take into account changes in gender roles, sex norms, and the emergence of new values and life goals. Together with structural changes in post-industrial labour markets, these factors have fundamentally altered the employment behaviour of women of post-war generations. It is widely believed that better educated women are the forerunners in the search for economic independence and self-fulfilment outside traditional family roles (Poole and Zeigler 1981; Debacker 2008).

With respect to the employment behaviour of less educated women, expectations are generally more ambivalent. On the one hand, it is assumed that new values and ideas have changed more slowly among the less educated. On the other hand, these groups have been under greater economic pressure to work. Oppenheimer (1994) emphasises the deterioration of men's employment opportunities in this context. Growing unemployment and rising labour market risks have worsened the economic situation of less educated males. Since educational homogamy is high in most societies (Oppenheimer 1997; Blossfeld and Timm 2003; Schwartz and Mare 2005), it can be expected that less educated women, who often have less educated partners, have come under increasing pressure to seek paid employment.

However, even as the pressure on less educated women to enter the labour market has become more severe, the job opportunities available to them have deteriorated. This is particularly true for (western) Germany, where the labour market is highly segmented by occupations and formal qualifications, and the segment of low-paid service jobs is 
rather small (Shavit and Müller 2000). Under this regime, individuals without formal vocational degrees have experienced increasing problems in accessing the labour market.

Another important issue in this context is that the size of the group of less educated women has declined since the 1970s. With declining numbers, women without formal qualifications are becoming, prima facie, more socially selective and they face higher risks of social exclusion (Solga 2002). McDonald (2000, p. 10) goes a step further when he argues that, as a response to their bleak employment chances, women who are systematically excluded from the labour market might consider parenthood as an alternative to a career outside the home. According to this line of reasoning, less educated mothers are increasingly becoming a self-selected group with a low labour market attachment.

\section{The context of social policy}

The participation of women, and in particular of mothers, in the labour force is not only influenced by individual resources, but also by the incentives and constraints imposed by social policies (Sainsbury 1999; Orloff 2002; Gornick and Meyers 2004, Gash 2008). The German 'conservative' and 'familialistic' welfare state supports mothers who stay at home and take care of their children, while it does little to help mothers who work (for an overview, see Ostner and Schmitt 2007).

Parental leave regulations were introduced in 1986 to improve the compatibility of work and family life. However, this policy has resulted in a slower return of mothers to the labour market. This trend has been reinforced by the extension of parental leave to three years in 1992 (Ondrich et al. 1996; Gottschall and Bird 2003; Weber 2004). The German tax system allows joint taxation for married couples, which is why it has been criticised for its 'housewife bonuses' (Sainsbury 1999, p. 195). What is, however, most relevant in determining a mother's labour market participation is the low availability of public day care arrangements for children. There is hardly any day care for children below the age of three. For older children, part-time day care exists, but the availability of full-time care is restricted (Deutsches Jugendinstitut 2005). ${ }^{1}$ 
While structural constraints prevent mothers from working full-time, conditions for working part-time have improved, particularly since the 1980s, when more flexible jobs in the service sector became available. In 2001, a law on part-time and fixed-term contracts ('Gesetz über Teilzeitarbeit und befristete Arbeitsverträge') was introduced to make it easier for people to work part-time. However, its effect in supporting employment among mothers is highly debated (Schmidt 2001).

\section{Discussion: A growing educational divide in mothers' employment?}

To sum up, the literature in Britain and the US suggests that both well educated and less educated women (with and without children) have increasingly entered the labour market in recent decades. In particular, the pressure on the less educated to act as family breadwinners has been mounting because the position of men in the labour market has become weaker (Oppenheimer 1994). Following this line of reasoning, one would expect to find that, also in Germany, less educated mothers have been increasingly pushed into the labour market over the past two decades. However, pressure of this kind has been weaker in the German case, where the 'homemaker model' is still generously subsidised. The German tax system provides stronger work disincentives for women with less education, as tax relief is greater when the income differences of the partners are larger (Dingeldey 2001). For this reason, it may be expected that, in particular, less educated women with highly educated partners are less likely to work. In addition, the income-related parental leave benefits should have a negative impact on the employment decisions of less educated women.

A critical question for our investigation is whether social policy changes have indirectly intensified educational differences in maternal employment patterns. Since the duration of parental leave was extended stepwise during the late 1980s and early 1990s, it could be assumed that, along with these changes, the educational divide in employment patterns also increased. Furthermore, it would be expected that worsening labour market opportunities encouraged less educated women to follow the 'homemaker model'. 
In essence, it has been argued that, in western Germany over the past three decades, the employment behaviour of mothers has developed differently between the different educational groups. The incentives provided by tax and transfer regulations, combined with less favourable employment opportunities for the less educated, and amplified by a rigid, highly regulated labour market, suggest that, in Germany, employment differentials between highly and less educated mothers have been increasing in recent decades. It has further been argued that this development has resulted in a polarisation of employment patterns between well educated and less educated mothers. While better educated women are more frequently able to combine a career with having children, labour market opportunities for the less educated have deteriorated.

\section{Data and variables}

The empirical investigation draws on data from the scientific use files of the German micro-censuses of the years 1976, 1982, 1989, 1996, 2000 and 2004. The files represent 0.7 percent samples of households in Germany. The micro-census questionnaire has remained relatively unchanged over these years, enabling researchers to make long-term comparisons with respect to a broad range of socioeconomic variables (Schimpl-Neimanns 1998). Being a household survey, the microcensus provides information about the number and ages of children living in the household, as well as about the characteristics of the respondents' partners. The microcensus does not provide information about the number of children of whom the respondents are the biological parents, which is why it is necessary to reconstruct the number of children from those living in the same 'family unit'. ${ }^{2}$ The investigation is restricted to women in the age range 18 to 45 who have children who live in the same household. The multivariate analysis will be restricted, furthermore, to women who were not in education at the time of the interview (for an overview of the sample size, see Table 1). Since there were very few mothers in education (see Table 2), this does not reduce the sample size significantly. Altogether, data on 251,184 women are used in the multivariate analysis. 
The dependent variable in the investigation is the employment status of women. The definition of 'employment status' adhered to is that used by Statistisches Bundesamt (German Statistical Office), which follows the recommendations of the International Labour Organization (Rengers 2004). Individuals are classified as employed when they are working at least one hour a week. They are considered unemployed if they have been actively seeking employment during the last three weeks before or during the reference week. They are classified as not in the labour force when they are not working and do not fit the criteria of the non-employed. Respondents who are not in the labour force are further differentiated by whether or not they are in education at the time of the interview. The employed are further differentiated by their working hours: that is, a distinction is made between full-time employment (30 or more hours per week), part-time employment (15 to 29 hours per week) and marginal employment (less than 15 hours per week). A further category includes women who report being employed, but whose working hours are equal to zero. In most cases, these respondents are on parental or another kind of leave.

The main independent variable is the educational level of the respondent. A distinction is made between individuals with no degree, a vocational certificate, and a tertiary degree. As previously mentioned, the information provided about children is restricted to those living in the household at the time of the interview. A distinction is made between women with no, one, two and three or more children. The age of the youngest child is located in one of five categories (ages 0 to 2, ages 3 to 5, ages 6 to 9, ages 10 to 15 and ages 16 or older). The respondent's age is classified into one of four groups (ages 18 to 25, ages 26 to 30, ages 31 to 35, and ages 36 to 45). Furthermore, respondents are grouped according to their marital status (single, married, divorced/ widowed). The educational level of the married woman's partner is also taken into account. One control variable is citizenship, distinguishing between respondents with Germans citizenship and others. Respondents with dual citizenship were classified as 'other'. In addition, the population size of the city of residence (under 20,000, 20,000 to 500,000 , and more than 500,000 ) is taken into account.

Table 1 presents a descriptive overview of the variables used in the multivariate analysis. The changes in demographic behaviour that have occurred since the 1970s 
are clearly visible in the composition of the sample. A greater number of women have earned a higher educational degree over the years. In 1976, only three percent had a tertiary degree; while in 2004, four times as many had one. The proportion of women without a vocational degree has declined over the years. In 1976, 43 percent of mothers aged 18 to 45 had neither a vocational nor a tertiary degree, but in 2004, this was true for no more than 22 percent.

[Table 1 about here]

\section{Results}

In the empirical analysis, the descriptive findings on the changing patterns of mothers' full-time, part-time and non-employment are first displayed. Next, the results from a multinomial logistic regression on the determinants of full-time, part-time and nonemployment are presented.

In general, labour force participation rates for women in western Germany have steadily increased since the 1970s. The rise in labour force participation rates largely results from changes in mothers' behaviour, while the labour force participation rates of childless women have remained rather unchanged. Table 2 shows the changes in employment behaviour of mothers. As can be seen from the upper panel of the table, part-time and marginal employment rates have strongly increased. Between 1976 and 2000, the proportions of mothers in marginal employment have risen more than fourfold, and the share of those in part-time employment has grown by more than 50 percent. Since 2000, the share of part-time employed mothers has not increased significantly, despite the fact that a change in legal regulations in 2001 facilitated parttime work. The development of full-time work displays a different pattern. There has been a substantial decline in the share of full-time employed mothers since the 1970s. In 1976, 24 percent of mothers worked full-time; however, by 2004, no more than 19 percent were in full-time employment.

Separate analyses by educational level show that, among the less educated, the decline in full-time employment has been particularly strong, while at the same time, this 
group has experienced a substantial rise in unemployment and marginal employment. For those with a medium level of education, a strong increase in part-time and a decline in full-time employment rates can be observed. The decline in full-time employment among the medium educated has, however, been smaller than among less educated women. Notably, changes in marginal employment match the pattern seen among women with low levels of education. For the highly educated, full-time employment rates have also declined, while marginal and part-time employment rates have increased. However, the changes are much less pronounced than for the other educational categories.

To sum up these descriptive findings: there has been a rapid decline in full-time employment rates among the less educated, a strong increase in part-time employment among women with vocational degrees, and only gradual changes in behaviour for tertiary educated mothers.

[Table 2 about here]

To analyse the factors that determine mothers' employment, multinomial logistic regression models are used. For this part of the analysis, three states are distinguished: full-time employment (30 hours or more per week), part-time employment (1-29 hours per week) and non-employment (leave, unemployment and not in the labour force). Mothers who are in education were excluded from the study population. In the first model, the effects of women's characteristics on their employment status are analysed. The model takes into account women's ages, their educational and marital status, the number of children in the household, the age of the youngest child, the calendar year, and, serving as control variables, the size of their city of residence and their citizenship. In a second model, the partners' educational status is also included. Since there is no information on the characteristics of unmarried partners, the latter analyses are restricted to married women.

Model 1 in Table 3 presents the results of the analysis that includes all women. Regarding the determinants of full-time versus non-employment, there is a negative time trend in a mother's full-time employment. Compared with 1976, women with 
children have 21 percent lower odds of being in full-time employment in 2004. Mothers with a higher educational level are substantially more likely to have a fulltime job than their less educated counterparts. Where the control variables are concerned, one finds that, as expected, the chances of being in full-time employment are lower for women with more than one child, and they strongly increase with the age of the youngest child who lives in the household. The age of the mother has a moderate impact on full-time employment, with women aged 26-30 having the highest chances of working full-time. Foreign mothers are more likely to work full-time than German mothers. Surprisingly, the odds of working full-time are elevated for mothers who live in villages or small towns, compared to mothers who live in medium or large towns. In line with previous studies for Germany (see Drobnič 2000, p. 144), nonmarried women work full-time more often than married women.

Part-time employment follows a somewhat different pattern. The chances that a mother will be working part-time have significantly increased over time, and they are less dependent on the woman's marital status (with married women being slightly more likely to be employed part-time than single women). Foreign mothers are less likely to work part-time than German mothers. While these results differ from the determinants of full-time employment, the impact of education is the same: the higher the level of education, the higher the chances of being in part-time work.

Model 2 provides results regarding the role of the partner's educational level in determining a woman's employment behaviour. When the spouse has a tertiary degree, the odds that a woman will work full-time are greatly reduced, and the odds that she will work part-time are somewhat lowered as well. On the whole, this empirical pattern confirms the male breadwinner assumption, i.e., in the context of the German welfare state, mothers feel less economic pressure to seek paid employment when they live with a highly educated spouse.

[Table 3 about here] 
Next, the education-specific developments over time have been examined in more detail. Have educational differentials in the employment of mothers increased since the 1970s, resulting in a pattern of polarisation in mothers' employment by educational level? To answer this question, an interaction between the mothers' education and calendar year (Table 4) is applied. Quite unexpectedly, the results show that full-time employment rates declined in all educational groups. For the less educated women, the odds of working full-time fell by 56 percent between 1976 and 2004. In the other educational categories, the chances of being in full-time employment declined less markedly. In essence, larger differences in full-time employment are found in 2004 than in 1976. In 2004, the odds of working full-time were 5.3 (2.31/0.44) times higher among women with a tertiary degree than for women with no degree. In 1976, the corresponding ratio was 3.3. Regarding part-time employment, there is an increase that applies to all three of the educational categories. Again, the dynamics differ by educational level. Women with university degrees had by far the highest chances of working part-time in 1976; however, these chances have not increased much over time. By contrast, less educated women have experienced a considerable increase in part-time employment rates. Finally, the strongest increase can be seen among women with vocational degrees. Despite the different dynamics of working part-time, the resulting pattern remains clearly stratified by education: in 2004, the odds of working part-time among the less educated were roughly 50 percent lower than among the medium educated, and 60 percent lower than among the highly educated.

[Table 4 about here]

Finally, the impact of the partner's education on maternal employment and its change over time is considered. If the assumption is correct that the position of men in the labour market has become weaker, and that men's ability to fulfil the role of family bread winner has declined, women might be increasingly pushed to become the family breadwinner, thereby substituting or complementing the male partner's role. This pressure should be highest for women whose partners have little formal education. 
However, the results presented in Table 5 give a different impression. Women whose partners have no degrees have become less likely to be employed full-time. Meanwhile, the odds that women whose partners have vocational or tertiary degrees will be in full-time employment have remained fairly stable over time. As a result, the partner's educational resources matter much less in 2004 than they did in 1976. Regarding part-time employment, the patterns are slightly different. On the one hand, the chances of being part-time employed increased for all mothers. However, the dynamics have been much less pronounced for women whose partners have no formal degree, compared to the other two categories. Hence, there is no indication that mothers are being pushed increasingly into the labour market because of the declining job prospects of males. Rather, the results confirm the assumption that the less educated have become more likely to be excluded from the labour market.

[Table 5 about here]

\section{Conclusions}

In this paper, changes over almost 30 years in maternal employment patterns in western Germany were examined using micro-census data which have only recently become available for research purposes. In addition to giving a descriptive account of the development in mothers' employment, the question of whether there is a growing educational divide in employment patterns was raised. While many studies in recent years have addressed the issues of work-life balance, part-time employment, and work preferences of women in contemporary societies, the focus of this article was on the development of the full-time employment rates of mothers, which is particularly relevant when examining issues of gender inequality in society and within the family.

In the literature, the general understanding is that, since the 1960s, modern societies have been moving away from the traditional male breadwinner model. There is no doubt that this is also true for western Germany. As expected, the homemaker model is being gradually replaced by a growing number of mothers working part-time or 
marginally. However, this investigation has also produced some unexpected findings: most notably, that full-time employment rates in western Germany steadily declined during that period. In other words, the process of increasing maternal labour force participation has been accompanied by a reduction in full-time employment. The finding that, in the mid-1970s, it was more common for mothers to be employed fulltime than it is in contemporary western Germany, is at odds with conventional wisdom, as well as with standard sociological reasoning on changing work behaviour, family models and gender roles. In terms of family breadwinner models, it can then be asserted that there is no evidence of an increase in the dual breadwinner family. The evidence is much more in favour of a consolidation of the male breadwinner model, which is nowadays typically combined with some kind of female part-time employment.

With respect to educational differentials, the results have been partially counterintuitive as well. While full-time employment rates declined among all educational groups, the most pronounced changes have occurred among less educated mothers. In essence, this trend has produced a growing educational divide in the full-time employment of mothers, with full-time employment now becoming more than ever a minority model primarily pursued by better educated women with children. Even though the trends observed with respect to part-time (including marginal) employment pointed to a different direction (i.e., increasing rates of part-timers), they reinforced the finding of growing educational disparities. Part-time employment has not only become the most prevalent labour force participation model for mothers; it is also strongly stratified by education.

It is beyond the scope of this article to give a conclusive answer about the causes of the decline in full-time employment rates that has occurred specifically among less educated mothers. It seems straightforward to assume, however, that two different factors have contributed to this pattern. For the less educated women, labour market opportunities have been steadily worsening over the last three decades. At the same time, German family policies have strengthened the incentives for mothers to reduce their labour market activities and stay at home to care for their small children. While measures to extend parental leave had been designed to give women a 'free choice' between work and family life, the empirical evidence presented in this article suggests 
that less educated mothers in particular have taken advantage of these policy options, whereas the more highly educated have had better opportunities - and probably a stronger motivation as well - to sustain their careers.

Whatever the exact mechanisms that have produced the growing educational divide in mothers' working patterns in western Germany, the fact that full-time employment is nowadays more than ever a domain of highly educated mothers has some obvious consequences. It suggests that the dual breadwinner model is becoming socially more selective, and hence that the distribution of economic resources is becoming more unequal at the household level. As a consequence, social inequality is expected to rise between families in West Germany. 


\section{Acknowledgements}

This work was supported by the German Council for Social and Economic Data and the Federal Ministry of Education and Research. The article has benefited from helpful comments and suggestions of the editors and anonymous referees of WES. We would also like to thank Sebastian Böhm for his support at an earlier stage of this project.

\section{References}

Blossfeld, H.P. (ed.) (1995) The New Role of Women: Family Formation in Modern Societies. Boulder: Westview Press.

Blossfeld, H.P. \& Drobniĉ, S. (eds) (2001) Careers of Couples in Contemporary Societies: From Male Breadwinner to Dual Earner Families. Oxford: Oxford University Press.

Blossfeld, H.P. \& Hakim, C. (eds) (1997) Between Equalization and Marginalization: Women Working Part-Time in Europe and the United States of America. Oxford: Oxford University Press.

Blossfeld, H.P. \& Timm, A. (eds) (2003) Who Marries Whom? Educational Systems as Marriage Markets in Modern Societies. Dordrecht: Kluwer.

Bonney, N. (2005) 'Overworked Britons? Part-time work and work-life balance', Work, Employment and Society 19: 391-401.

Bothfeld, S., Schmidt, T. \& Tobsch, V. (2005) Erosion des Ernährermodells? Die Erwerbstätigkeit von Frauen mit Kindern unter drei Jahren. Berlin: Bundesministerium für Familie, Senioren, Frauen und Jugend.

Crompton, R., Brockmann, M \& Lyonette, C. (2005): 'Attitudes, women's employment and the domestic division of labour: a cross-national analysis in two waves', Work, Employment and Society 19: 213-233.

Daly, M. (2005) 'Changing Family Life in Europe: Significance for State and Society’, European Societies 7: 379-98.

Debacker, M. (2008): Care strategies anong high- and low-skilled mothers. A world of difference, Work, Employment and Society 22: 527-545.

Dex, S. \& Bond, S. (2005), 'Measuring work-life balance and its covariates', Work, Employment and Society 19: 627-37.

Deutsches Jugendinstitut (2005) Kindertagesbetreuung im Spiegel der Statistik. München: Deutsches Jugendinstitut. 
Dingeldey, I. (2001) 'European Tax Systems and their Impact on Family Employment Patterns', Journal of Social Policy 30: 653-72.

Drobnič, S. (2000) 'The Effects of Children on Married and Lone Mother's Employment in the United States and (West) Germany', European Sociological Review 16: 137-57.

Duncan, S., Edwards, R., Reynolds, T. \& Alldred, Pam (2009) 'Motherhood, paid work and partnering: values and theories', Work, Employment and Society 17: 309330.

Esping-Andersen, G. (2009) The Incomplete Revolution. Adapting to Women's New Roles. Cambridge/Malden: Polity Press.

Gash, V. (2008): Preference or constraint? Part-time workers' transitions in Denmark, France and the United Kingdom, Work, Employment and Society 2008 22: 655-674.

Gornick, J.C. \& Meyers, M.K. (2004) 'Welfare Regimes in Relation to Paid Work and Care’, in: Giele, Z. \& Holst, E. (eds) Changing Life Patterns in Western Industrial Societies. Amsterdam: Elsevier: 45-67.

Gottschall, K. \& Bird, K. (2003) 'Family Leave Policies and Labour Market Segregation in Germany: Reinvention or Reform of the Male Breadwinner Model?', Review of Policy Research (Special Issue on Gender and Work Place Policies) 20: 115-34.

Haas, B., Steiber, N, Hartel, M \& Wallace, C. (2006) 'Household employment patterns in an enlarged European Union’, Work, Employment and Society 20: 751-771.

Hakim, C. (2000) Work-Lifestyle Choice in the 21st Century: Preference Theory. Oxford: Oxford University Press.

Klement, C. \& Rudolph, B. (2004) 'Employment Patterns and Economic Independence of Women in Intimate Relationships', European Societies 6: 299-318.

Kurz, K. (1998) Das Erwerbsverhalten von Frauen in der intensiven Familienphase. Opladen: Leske + Budrich.

Lengerer, A., Janßen, A. \& Bohr, J. (2007): 'Familiensoziologische Analysepotenziale des Mikrozensus’, Zeitschrift für Familienforschung 2: 186-209.

Lewis, J. (1992) 'Gender and the Development of Welfare Regimes', Journal of European Social Policy 2: 159-73.

Lichter, D.T. \& Eggebeen, D.J. (1994) 'The Effect of Parental Employment on Child Poverty', Journal of Marriage and the Family 56: 633-45.

Mandel, H. \& Semyonov, M. (2006) 'Welfare State Paradox: State Interventions and Women’s Employment Opportunities in 22 Countries', American Journal of Sociology 111: 2006.

Maxwell, N.L. (1990) 'Changing Female Labour Force Participation: Influences on Income Inequality and Distribution', Social Forces 68: 1251-66.

McDonald, P. (2000), 'Gender Equity, Social Institutions and the Future of Fertility', Journal of Population Research 17: 1-16. 
McLanahan, S. (2004) 'Diverging Destinies: How Children Fare under the Second Demographic Transition', Demography 41: 607-27.

Mincer, J. (1974) Schooling, Experience, and Earning. New York: National Bureau of Economic Research.

OECD (2004) Female Labour Force Participation: Past Trends and Main Determinants in OECD Countries. Paris: OECD.

Ondrich, J., Spiess, C.K. \& Yang, Q. (1996) 'Barefoot and in a German Kitchen: Federal Parental Leave and Benefit Policy and the Return to Work after Childbirth in Germany', Population Economics 9: 247-66.

Oppenheimer, V.K. (1994) 'Women's Rising Employment and the Future of the Family in Industrial Societies’, Population and Development Review 20: 293-342.

Oppenheimer, V.K. (1997) 'Women's Employment and the Gain to Marriage: The Specialization and Trading Model', Annual Review of Sociology 23: 431-53.

Orloff, A.S. (2002) ‘Women’s Employment and Welfare Regimes: Europe and North America’, United Nations Research Institute for Social Development.

Ostner, I. \& Schmitt, C. (eds) (2007) Family Policies in Germany. Wiesbaden: VS Verlag für Sozialwissenschaften.

Pascall, G. \& Lewis, J. (2004) 'Emerging Gender Regimes and Policies for Gender Equality in a Wider Europe', Journal of Social Policy 33: 373-394.

Poole, K.T. \& Zeigler, H.L. (1981) 'The Diffusion of Feminist Ideology', Political Behavior 3: 229-56.

Rengers, M. (2004) 'Das international vereinbarte Labour-Force-Konzept', Wirtschaft und Statistik 12: 1369-83.

Sainsbury, D. (1999) 'Taxation, Family Responsibilities, and Employment', in Sainsbury. D. (ed.): Gender and Welfare State Regimes. Oxford: Oxford University Press: 185-209.

Schimpl-Neimanns, B. (1998) 'Analysemöglichkeiten des Mikrozensus', ZUMANachrichten 42: 91-122.

Schmidt, M. (2001): 'The right to part-time work under German law: Progress in or a Boomerang for equal employment opportunities?', Industrial Law Journal 30: 335352.

Schwartz, C.R. \& Mare, R.D. (2005) 'Trends in Educational Assortative Marriage', Demography 42: 621-46.

Shavit, Y. \& Müller, W. (2000) 'Vocational Secondary Education. Where Division and Where Safety Net?', European Societies 2: 29-50.

Solga, H. (2002) 'Stigmatization by Negative Selection: Explaining Less-Educated People's Decreasing Employment Opportunities', European Sociological Review 18: 159-178.

Sørensen, A. \& McLanahan, S. (1987) 'Married Women’s Economic Dependency, 1940-1980’, American Journal of Sociology 93: 659-87. 
Waite, L. \& Nielsen M. (2001) 'The Rise of the Dual-Worker Family 1963-1997', in: Hertz, R. \& Marshall, N. (eds) Working Families: The Transformation of the American Home. Berkeley: University of California Press: 23-41.

Weber, A.M. (2004) 'Wann kehren junge Mütter auf den Arbeitsmarkt zurück? Eine Verweildaueranalyse für Deutschland', ZEW-Discussion Papers 04-08.

Wielers, R. \& van der Meer, P. (2003) 'Lower Educated Workers and Part-Time Work: The Netherlands 1973-91’. Acta Sociologica 46: 307-321. 


\section{Tables}

Table 1: Description of sample used in multivariate analyses, women aged 18 to 45 with children, (column percent)

\begin{tabular}{|c|c|c|c|c|c|c|}
\hline & 1976 & 1982 & 1989 & 1996 & 2000 & 2004 \\
\hline \multicolumn{7}{|l|}{ Employment status } \\
\hline Full-time (30 hours and more) & 24.3 & 23.8 & 23.0 & 21.1 & 20.8 & 18.6 \\
\hline Part-time (1 - 29 hours) & 16.9 & 20.3 & 20.7 & 29.4 & 34.4 & 36.8 \\
\hline Other & 58.9 & 55.9 & 56.3 & 49.5 & 44.8 & 44.6 \\
\hline \multicolumn{7}{|l|}{ Size of city } \\
\hline Below 20,000 inhabitants & 42.4 & 40.7 & 42.3 & 44.6 & 44.5 & 43.8 \\
\hline 20,000-500,000 inhabitants & 40.1 & 42.0 & 43.1 & 41.7 & 42.0 & 42.7 \\
\hline 500,000 and more inhabitants & 13.8 & 12.6 & 14.6 & 13.7 & 13.5 & 13.5 \\
\hline Missing & 3.7 & 4.7 & -- & -- & -- & -- \\
\hline \multicolumn{7}{|l|}{ Citizenship } \\
\hline German & 93.5 & 91.4 & 89.8 & 88.6 & 88.3 & 87.4 \\
\hline Other & 6.5 & 8.6 & 10.2 & 11.4 & 11.7 & 12.6 \\
\hline \multicolumn{7}{|l|}{ Woman's age } \\
\hline Age 18 - 25 & 11.1 & 9.4 & 8.4 & 5.7 & 4.9 & 4.7 \\
\hline Age 26 - 30 & 16.9 & 17.0 & 20.2 & 16.2 & 13.2 & 11.3 \\
\hline Age 31 - 35 & 23.2 & 22.4 & 24.7 & 26.8 & 26.2 & 22.2 \\
\hline Age $36-45$ & 48.8 & 51.2 & 46.7 & 51.3 & 55.7 & 61.8 \\
\hline \multicolumn{7}{|l|}{ Number of children } \\
\hline 1 child & 38.4 & 40.8 & 44.2 & 40.3 & 39.4 & 38.9 \\
\hline 2 children & 38.6 & 41.3 & 41.4 & 43.6 & 43.9 & 44.5 \\
\hline 3 or more children & 23.1 & 17.9 & 14.3 & 16.2 & 16.7 & 16.6 \\
\hline \multicolumn{7}{|l|}{ Age of youngest child } \\
\hline Age 0 - 2 & 20.7 & 21.5 & 27.2 & 25.2 & 25.7 & 23.2 \\
\hline Age 3 - 5 & 19.9 & 15.5 & 17.7 & 20.0 & 18.3 & 19.9 \\
\hline Age 6 - 9 & 27.4 & 17.8 & 19.3 & 20.9 & 21.7 & 21.7 \\
\hline Age $10-15$ & 24.7 & 31.8 & 20.9 & 22.3 & 23.4 & 24.5 \\
\hline Age 16 or older & 7.3 & 13.4 & 14.9 & 11.6 & 10.9 & 10.7 \\
\hline \multicolumn{7}{|l|}{ Woman's educational degree } \\
\hline No degree & 43.2 & 36.9 & 28.3 & 25.2 & 22.4 & 21.8 \\
\hline Vocational degree & 46.2 & 55.3 & 62.6 & 59.7 & 62.1 & 62.1 \\
\hline Tertiary degree & 2.8 & 4.9 & 7.3 & 8.9 & 8.4 & 9.5 \\
\hline Missing & 7.9 & 2.9 & 1.7 & 6.1 & 7.1 & 6.5 \\
\hline \multicolumn{7}{|l|}{ Marital status } \\
\hline Married & 93.5 & 92.1 & 89.4 & 88.3 & 86.6 & 83.6 \\
\hline Single & 1.1 & 1.7 & 3.2 & 4.4 & 5.3 & 6.9 \\
\hline Divorced/widowed & 5.5 & 6.2 & 7.4 & 7.2 & 8.2 & 9.5 \\
\hline \multicolumn{7}{|l|}{ Partner's education *) } \\
\hline No degree & 18.7 & 16.4 & 13.7 & 14.0 & 13.0 & 13.2 \\
\hline Vocational degree & 67.5 & 68.1 & 67.6 & 62.0 & 62.4 & 61.5 \\
\hline Tertiary degree & 8.7 & 11.9 & 15.5 & 16.2 & 15.0 & 15.6 \\
\hline Missing & 5.2 & 3.7 & 3.2 & 7.7 & 9.6 & 9.7 \\
\hline Sample Size & 47,940 & 44,757 & 38,881 & 41,329 & 40,289 & 37,988 \\
\hline
\end{tabular}

Note: The sample includes women aged 18-45 with children who live in the same household and who are not in education.

*) only for married women

Source: Scientific-Use-File of the German micro-census 1976, 1982, 1989, 1996, 2000 2004, author’s calculations 
Table 2: Employment status of women with children (column percent)

\begin{tabular}{|c|c|c|c|c|c|c|}
\hline & 1976 & 1982 & 1989 & 1996 & 2000 & 2004 \\
\hline \multicolumn{7}{|l|}{ All women } \\
\hline Full-time (30 hours and more) & 24.2 & 23.7 & 22.9 & 20.9 & 20.7 & 18.5 \\
\hline Part-time (15 - 29 hours) & 13.7 & 16.2 & 16.4 & 19.8 & 21.5 & 22.5 \\
\hline Marginal (1 - 14 hours) & 3.2 & 4.1 & 4.2 & 9.4 & 12.7 & 14.0 \\
\hline Leave & 1.3 & 2.3 & 3.8 & 7.3 & 8.3 & 8.4 \\
\hline Unemployed & 2.0 & 3.7 & 6.8 & 3.9 & 3.4 & 5.4 \\
\hline Not in the labour force: other & 55.5 & 49.7 & 45.4 & 37.9 & 32.6 & 30.4 \\
\hline Not in the labour force: in education & 0.2 & 0.3 & 0.5 & 0.8 & 0.8 & 0.7 \\
\hline Total & 100 & 100 & 100 & 100 & 100 & 100 \\
\hline Sample Size & 48,056 & 44,894 & 39,074 & 41,673 & 40,611 & 38,260 \\
\hline \multicolumn{7}{|l|}{ No degree } \\
\hline Full-time (30 hours and more) & 25.8 & 24.6 & 22.4 & 18.0 & 17.6 & 13.7 \\
\hline Part-time (15 - 29 hours) & 11.4 & 13.1 & 11.2 & 13.0 & 13.9 & 13.3 \\
\hline Marginal (1 - 14 hours) & 3.0 & 3.6 & 3.4 & 8.2 & 11.6 & 12.1 \\
\hline Leave & 1.1 & 1.6 & 2.7 & 4.1 & 4.2 & 3.7 \\
\hline Unemployed & 2.2 & 4.1 & 7.6 & 5.1 & 5.1 & 8.2 \\
\hline Not in the labour force: other & 56.3 & 52.8 & 52.2 & 50.4 & 46.2 & 47.6 \\
\hline Not in the labour force: in education & 0.2 & 0.3 & 0.4 & 1.3 & 1.4 & 1.4 \\
\hline Total & 100 & 100 & 100 & 100 & 100 & 100 \\
\hline Sample Size & 20,734 & 16,572 & 11,065 & 10,551 & 9,154 & 8,415 \\
\hline \multicolumn{7}{|l|}{ Vocational degree } \\
\hline Full-time (30 hours and more) & 23.3 & 23.0 & 22.8 & 20.8 & 20.4 & 18.7 \\
\hline Part-time (15 - 29 hours) & 16.3 & 18.2 & 18.1 & 22.5 & 24.6 & 25.9 \\
\hline Marginal (1 - 14 hours) & 3.2 & 4.1 & 4.2 & 10.2 & 13.8 & 15.4 \\
\hline Leave & 1.4 & 2.6 & 4.3 & 8.6 & 9.8 & 9.8 \\
\hline Unemployed & 2.0 & 3.6 & 6.3 & 3.5 & 2.9 & 4.8 \\
\hline Not in the labour force: other & 53.6 & 48.3 & 43.9 & 33.9 & 28.0 & 25.0 \\
\hline Not in the labour force: in education & 0.1 & 0.1 & 0.3 & 0.6 & 0.5 & 0.4 \\
\hline Total & 100 & 100 & 100 & 100 & 100 & 100 \\
\hline Sample Size & 22,153 & 24,781 & 24,427 & 24,833 & 25,126 & 23,688 \\
\hline \multicolumn{7}{|l|}{ Tertiary degree } \\
\hline Full-time (30 hours and more) & 32.6 & 30.4 & 25.7 & 28.8 & 29.6 & 27.2 \\
\hline Part-time (15 - 29 hours) & 19.8 & 22.0 & 23.4 & 22.9 & 22.8 & 24.1 \\
\hline Marginal (1 - 14 hours) & 8.0 & 8.9 & 7.8 & 9.6 & 9.6 & 10.9 \\
\hline Leave & 2.7 & 4.1 & 4.6 & 9.2 & 10.2 & 11.3 \\
\hline Unemployed & 1.4 & 3.2 & 7.2 & 3.6 & 3.1 & 3.3 \\
\hline Not in the labour force: other & 35.1 & 31.0 & 30.8 & 24.9 & 23.3 & 22.1 \\
\hline Not in the labour force: in education & 0.4 & 0.4 & 0.5 & 1.1 & 1.5 & 1.1 \\
\hline Total & 100 & 100 & 100 & 100 & 100 & 100 \\
\hline Sample Size & 2,336 & 2,216 & 2,851 & 3,730 & 3,441 & 3,656 \\
\hline
\end{tabular}

Note: The sample includes women aged 18-45 with children who live in the same household. Employment rates of women for whom the information on their educational level is missing have not been displayed. Therefore, case numbers for women with no degree, vocational degree and tertiary degree do not add up to the case numbers for all women.

Source: Scientific-Use-File of the German micro-census 1976, 1982, 1989, 1996, 20002004 
Table 3: Multinomial logistic regression, determinants of mother's full-time, part-time and nonemployment (reference), multinomial odds ratios

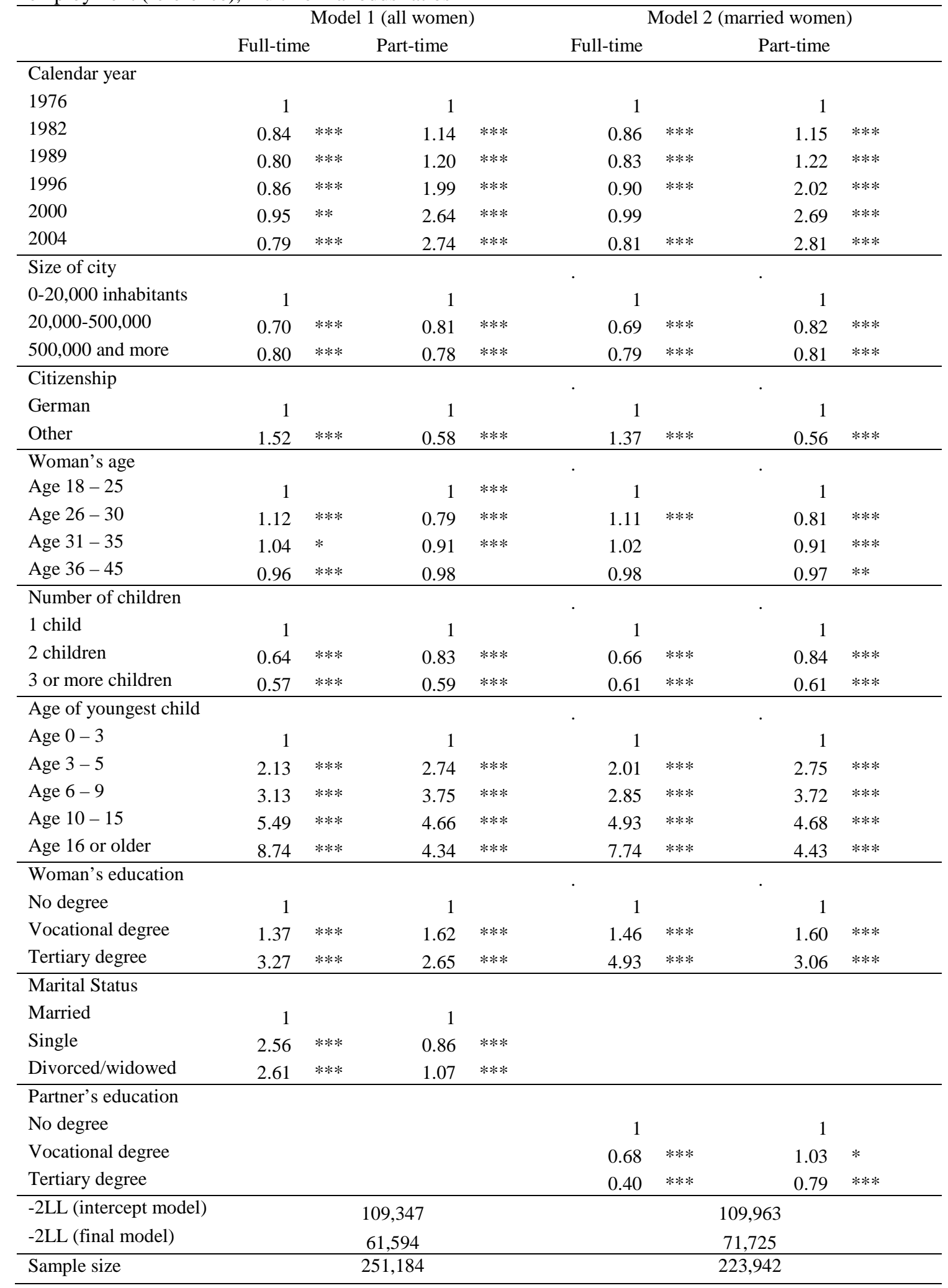

Note: Sample includes women aged 18-45 with children. Respondents in education have been excluded. It has been controlled for missing values for level of education and size of city. ${ }^{* * *} \mathrm{p}<0.01 ;{ }^{* *} \mathrm{p}<0.05$; ${ }^{*} \mathrm{p}<0.10$. Source: Scientific-Use-File of the German micro-census 1976, 1982, 1989, 1996, 20002004 
Table 4: Multinomial logistic regression, determinants of mothers' full-time, part-time and nonemployment (reference), multinomial odds ratios, interaction between calendar year and woman's education

\begin{tabular}{lllllll}
\hline Full-Time & 1976 & 1982 & 1989 & 1996 & 2000 & \multicolumn{1}{c}{2004} \\
\hline Woman's education & 1 & $0.81^{* * *}$ & $0.70^{* * *}$ & $0.60^{* * *}$ & $0.63^{* * *}$ & $0.44^{* * *}$ \\
$\quad \begin{array}{l}\text { No degree } \\
\text { Vocational degree }\end{array}$ & 1.04 & $0.92^{* * *}$ & $0.94^{*}$ & $1.08^{* * *}$ & $1.20^{* * *}$ & 1.02 \\
$\quad$ Tertiary degree & $3.27^{* * *}$ & $2.71^{* * *}$ & $1.98^{* * *}$ & $2.30^{* * *}$ & $2.47^{* * *}$ & $2.31^{* * *}$ \\
& & & & & & \\
\hline Part-Time & 1976 & 1982 & 1989 & 1996 & 2000 & 2004 \\
\hline Woman's education & & & & & & \\
$\quad$ No degree & 1 & $1.14^{* * *}$ & 1.05 & $1.70^{* * *}$ & $2.30^{* * *}$ & $2.16^{* * *}$ \\
$\quad$ Vocational degree & $1.41^{* * *}$ & $1.60^{* * *}$ & $1.75^{* * *}$ & $3.08^{* * *}$ & $4.14^{* * *}$ & $4.35^{* * *}$ \\
$\quad$ Tertiary degree & $4.12^{* * *}$ & $4.43^{* * *}$ & $3.95^{* * *}$ & $4.43^{* * *}$ & $4.73^{* * *}$ & $5.33^{* * *}$ \\
\hline
\end{tabular}

Note: Sample includes women aged 18-45 with children. Respondents in education have been excluded. Other variables in the model are size of city, citizenship, woman's age, number of children, age of youngest child, marital status. ${ }^{* * *} \mathrm{p}<0.01 ;{ }^{* *} \mathrm{p}<0.05 ;{ }^{*} \mathrm{p}<0.10$.

Source: Scientific-Use-File of the German micro-census 1976, 1982, 1989, 1996, 20002004 
Table 5: Multinomial logistic regression, determinants of mothers' full-time, part-time and nonemployment (reference), multinomial odds ratios, interaction between calendar year and partner's education

\begin{tabular}{lllllll}
\hline Full-Time & 1976 & 1982 & 1989 & 1996 & 2000 & 2004 \\
\hline Partner's education & & & & & & \\
No degree & 1 & $0.84^{* * *}$ & $0.68^{* * *}$ & $0.61^{* * *}$ & $0.63^{* * *}$ & $0.50^{* * *}$ \\
Vocational degree & $0.55^{* * *}$ & $0.47^{* * *}$ & $0.48^{* * *}$ & $0.53^{* * *}$ & $0.59^{* * *}$ & $0.49^{* * *}$ \\
$\quad$ Tertiary degree & $0.27^{* * *}$ & $0.26^{* * *}$ & $0.25^{* * *}$ & $0.34^{* * *}$ & $0.37^{* * *}$ & $0.32^{* * *}$ \\
\hline Part-Time & 1976 & 1982 & 1989 & 1996 & 2000 & 2004 \\
\hline Partner's education & & & & & & \\
$\quad$ No degree & 1 & $0.76^{* * *}$ & $0.64^{* * *}$ & 0.98 & $1.40^{* * *}$ & $1.49^{* * *}$ \\
$\quad$ Vocational degree & $0.58^{* * *}$ & $0.65^{* * *}$ & $0.69^{* * *}$ & $1.21^{* * *}$ & $1.62^{* * *}$ & $1.68^{* * *}$ \\
$\quad$ Tertiary degree & $0.40^{* * *}$ & $0.53^{* * *}$ & $0.63^{* * *}$ & $0.92^{* *}$ & $1.13^{* * *}$ & $1.18^{* * *}$ \\
\hline
\end{tabular}

Note: The sample includes married women aged 18-45 with children. Respondents in education have been excluded. Other variables in the model are size of city, citizenship, woman's age, number of children, age of youngest child, woman's education. ${ }^{* * *} \mathrm{p}<0.01 ;{ }^{* *} \mathrm{p}<0.05$; ${ }^{*} \mathrm{p}<0.10$.

Source: Scientific-Use-File of the German micro-census 1976, 1982, 1989, 1996, 2000 2004, own calculations 


\section{Dirk Konietzka}

Dirk Konietzka is Professor of Sociology at the Department of Social Sciences, Braunschweig Institute of Technology. His research interests are social stratification, family sociology, and life course research. He has worked on various aspects of changing life courses, in particular the transition from school to work, family formation and labour market transitions.

Address: Braunschweig Institute of Technology, Department of Social Sciences, Bienroder Weg 97, D-38106 Braunschweig

Email: d.konietzka@tu-bs.de

\section{Michaela Kreyenfeld}

Michaela Kreyenfeld is a research scientist at the Max Planck Institute for Demographic Research and a junior professor at Rostock University. Her research interests are family sociology, life course research and social policy. Among other things, she has looked at the extent to which child care policies influence employment and fertility decisions. One of her particular interests has been to investigate the demographic development in East Germany after unification.

Address: Max Planck Institute for Demographic Research, Konrad-Zuse Str. 1, D18057 Rostock

Email: kreyenfeld@demogr.mpg.de 


\section{Endnotes}

1 Since 2005, the German government has implemented major family policy reforms. Given that this study focuses on the period before 2005, the new policy regulations are not discussed any further.

2 In order to identify a 'family unit', the 'traditional concept of the family' ('traditionelles Familienkonzept') was used here (see Lengerer et al. 2007). This definition and additional information on the position in the family unit has been used to generate the number of children and the age of the youngest child for all women in the sample. 